\title{
ANALYTIC HIERARCHY PROCESS FOR EVIDENCE-BASED POLICY MAKING
}

\author{
Yoichi Iida \\ Suwa University of Science \\ Nagano, JAPAN \\ E-mail: youichi.iida@gmail.com
}

\begin{abstract}
These days the Japanese government pushes forward an approach of evidence-based policy making in their policy making and policy evaluation. As a result, it is a similar situation in the local government. The purpose of this paper is to show an actual example using the Analytic Hierarchy Process to make evidence. Most evaluators tend to ask for objective numbers as evidence, though policies, in particular in the local government, are for people who live there, and making policy is a kind of decision making by them. From the point of view, the Analytic Hierarchy Process as a group decision-making method is very helpful and useful for policy-making of the inhabitant participation, because the administrative activity should be democratic. In this paper, I showed that the committee consisting of a representative citizen of Okaya city, where the population is less than fifty thousand, evaluated the projects of their commerce revitalization plan using the Analytic Hierarchy Process. The meeting held eight times before this evaluation. Almost all of the evaluation results are concordant to that in advance of administrative officers, but the evaluation of one project was changed according to the committee's result. Consequently, we could complete "Okaya city commerce revitalization plan" based on the agreement.
\end{abstract}

Keywords: evidence-based policy making, participatory evaluation, relative evaluation.

\section{Introduction}

These days the Japanese government pushes forward an approach of evidence-based policy making (EBPM) in their policy making and policy evaluation. Traditional episode-based policy-making is hard to improve the formed policy to the next year and utilize the PDCA (Plan, Do, Check, Act) cycle, which is one of the popular tools companies use in order to improve their business.

Accordingly, the local government began to work on EBPM. In the case of the local government, it is generally applied to not policies, but projects, because the annual revenue is finally distributed to them. The target of this paper is a Japanese local government of which the population and the annual revenue are gradually decreasing. Their populations are around fifty thousand people. This number is a condition to become a city by law. Certainly, there are some cities in Japan where the population is more than five hundred thousand. They have also some issues but are at least rich.

This paper shows an actual example of making evidence by the Analytic Hierarchy Process (the AHP). Many evaluators tend to ask for objective numbers as evidence. However, policies, in particular in the local government, are for people who live there, 
and making policy is a kind of decision making by them. From this viewpoint, the AHP is very helpful and useful for policy-making of inhabitant participation as a group decision making. It is because the administrative activity should be democratic.

In this paper, I treated the commerce activation plan of Okaya city, where the population is less than fifty thousand. Finally, the committee decided on the synthesized evaluation of projects using the AHP, which was utilized in the budget request of the next fiscal year.

This work was supported by JSPS Grants-in-Aid for Scientific Research "KAKENHI", Number JP20K01480.

\section{Literature Review}

For the last several decades, the importance of administrative evaluation has been increasing in Japan, because many local governments have had financial problems. We used some tools like Output indicator, KPI (Key performance indicator), logic model, and so on, although we began noticing that these tools do not function to evaluate policies and projects well. Thereafter, evidence-based policy making method to build policies or projects came to attract attention to enhance the effectiveness and efficiency of them (Stoker \& Evans, 2016). It is not clear what is an evidence-based policy making method in the administrative activity in Japan and there are a lot of arguments and studies for it, for example (Ohashi, 2020).

\section{Objectives}

This paper aims to present an actual example which show that the AHP is helpful and useful in the context of deciding the priority of projects in administrative activities. It is expected that this way can rise inhabitants' satisfaction.

In October 2017, I was elected a member of "Okaya city commerce activation meeting" as a person with knowledge and experience. This meeting was launched to draw up policies and projects to enhance the city's commerce, that is "Okaya city commerce activation plan". The member except for me consisted of 12 people who were representatives of the commerce societies in Okaya city and administrative officers arranged this meeting.

After a meeting was held eight times, we drew up three basic strategies, which had six projects, three projects and two projects, respectively. In this paper, I treated just one basic strategy and its six projects. This strategy is "Shopping district attractive improvement strategy" and the six projects are the following; $\left(\mathrm{P}_{1}\right)$ Support of the role improvement of shopping precincts, $\left(\mathrm{P}_{2}\right)$ Support for equipment investment for attractive improvement of commerce, $\left(\mathrm{P}_{3}\right)$ Support for founding and new business, $\left(\mathrm{P}_{4}\right)$ Support for business succession, $\left(\mathrm{P}_{5}\right)$ Propulsion of countermeasure for vacant stores, and $\left(\mathrm{P}_{6}\right)$ Propulsion of store information provision.

Furthermore, to complete this, we needed to give these projects the relative priorities for a budget demand of the next fiscal year. I suggested dividing priority into importance and urgency and moreover, made a proposal to use the concept of the AHP. The AHP can relatively evaluate projects with respect to these criteria and at the same time, gather the opinion of the committee. To make numerical values by the AHP was to make evidence in a sense. This idea was accepted by the committee. 
Thus, we had the relative importance and urgency of all projects. A part of this result was slightly different from one by administrative officers, but the evaluation about it was adopted because it was a thing decided democratically by citizens. Finally, we could draw up three policies and eleven projects based on the agreement after a few reviews by the public comment. In the remaining part of the paper I explained the method that I used there.

\section{Methodology}

I showed only one basic strategy, Shopping district attractive improvement strategy. I used the questionnaire method.

\section{4-1. Questions for the AHP}

The questions to acquire numerical values are the following;

(Question 1) Answer the following three questions for the importance and urgency of six projects $\mathrm{P}_{1}$ to $\mathrm{P}_{6}$.

(Question 1-1) First, rank the projects with respect to importance. Then, write the name of the project from a more important project sequentially from the second row in the second column. Finally circle the most appropriate adjective in $<>$ in the cell in the third column.

\begin{tabular}{|c|c|c|}
\hline Ranking & $\begin{array}{l}\text { Fill in } \\
\text { project's name }\end{array}$ & Circle the most appropriate adjective in $<>$. \\
\hline $\begin{array}{c}\text { The most } \\
\text { Important project }\end{array}$ & & $\begin{aligned}<\text { A little more / More / Much more }> \\
\text { important than the 2nd place }\end{aligned}$ \\
\hline 2 & & $\begin{aligned}<\text { A little more / More / Much more }> \\
\text { important than the 3rd place }\end{aligned}$ \\
\hline 3 & & $\begin{aligned}<\text { A little more / More / Much more }> \\
\text { important than the 4th place }\end{aligned}$ \\
\hline 4 & & $\begin{aligned}<\text { A little more / More / Much more }> \\
\text { important than the 5th place }\end{aligned}$ \\
\hline 5 & & $\begin{aligned}<\mathrm{A} \text { little more / More / Much more }> \\
\text { important than the } 6 \text { th place }\end{aligned}$ \\
\hline 6 & & . \\
\hline
\end{tabular}

(Question 1-2) First, rank the projects with respect to urgency. Then, write the name of the project from a higher emergent project sequentially from the second row in the second column. Finally circle the most appropriate adjective in $<>$ in the cell in the third column.

I omit the question table about the urgency for want of space in here.

(Question 1-3) Write any additional comments about the importance and urgency of projects of this basic strategy.

4-2. Calculation of weights as the committee from the result of the questionnaire In this section, I will explain how to calculate the final magnitude of the importance of projects, which is the same as that of the urgency. This method is slightly different from the AHP not to do all comparisons among projects.

(Step 1) Calculation of the individual importance of projects 
First, let the magnitude of importance of the project of the lowest rank, in this case, 6th place, be 1. Next, when the magnitude of the project of rank $n$ is $s$, let that of the project of rank $(n-1)$ be $s$ multiplied by $k$, where $k$ is a converted value according to the following Table 1. Repeat this procedure until all magnitude is calculated.

Table 1. The fundamental scale

\begin{tabular}{ccc} 
Definition of importance & Intensity & Definition of urgency \\
\hline A little more important & 3 & A little higher emergent \\
More important & 5 & Higher emergent \\
Much more important & 7 & Much higher emergent
\end{tabular}

Here, I note that I carried out sensitivity analysis about the numerical values in Table 1 , but the final ranking of projects was the same as this case.

(Step 2) Calculation of the importance of projects as the committee

As in group decision making, the importance of a project as the committee was calculated by geometric means of the individual importance for the project. Finally, I normalized these values to the final importance of projects, which means that the sum of the importance of projects is 1 as in the AHP.

\section{Data Analysis}

The summaries of this investigation are as follows: The investigation purpose is to relatively evaluate the importance and urgency of projects with respect to each basic strategy. The enforcement period is from July 22 to August 23 in 2018. The distribution and collection survey method is the detention method using a questionnaire. The respondents are 11 of 12 people who are Okaya city commerce activation meeting committees. A person who is a long-term absentee was excluded by his hope. The answer rate was $100 \%$ to 11 people.

Table 2. Magnitudes of importance and urgency of projects, resp.

\begin{tabular}{l|cccccc|c} 
Project & $\mathrm{P}_{1}$ & $\mathrm{P}_{2}$ & $\mathrm{P}_{3}$ & $\mathrm{P}_{4}$ & $\mathrm{P}_{5}$ & $\mathrm{P}_{6}$ & Total \\
\hline Importance & 0.296 & 0.552 & 0.026 & 0.005 & 0.081 & 0.040 & 1 \\
Urgency & 0.097 & 0.784 & 0.028 & 0.004 & 0.051 & 0.036 & 1
\end{tabular}

Table 3. The number of times chosen as the most important or urgent project, resp

\begin{tabular}{l|cccccc|c} 
Project & $\mathrm{P}_{1}$ & $\mathrm{P}_{2}$ & $\mathrm{P}_{3}$ & $\mathrm{P}_{4}$ & $\mathrm{P}_{5}$ & $\mathrm{P}_{6}$ & Total \\
\hline Importance & 4 & 4 & 0 & 0 & 3 & 0 & 11 \\
Urgency & 2 & 7 & 0 & 0 & 1 & 1 & 11
\end{tabular}

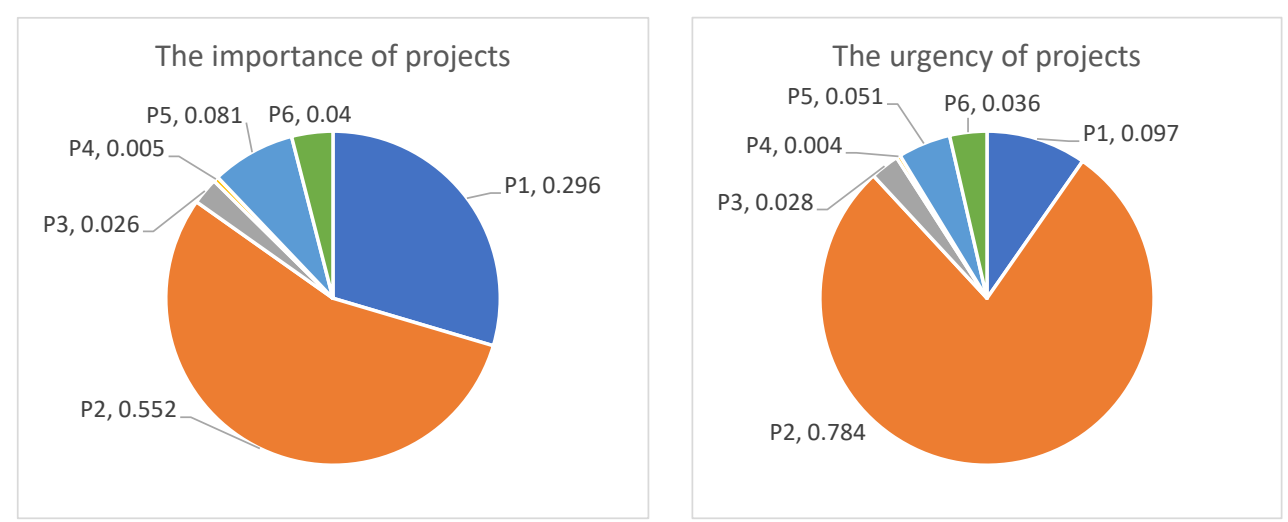

Figure 1. Pie charts about importance and urgency for six projects, $\mathrm{P}_{1}$ to $\mathrm{P}_{6}$. 
I obtained Tables 2 and 3 by the procedure explained in Section 4 . Table 3 is the number of times which was chosen as the most important or urgent project, resp. We expect that the projects that have a high ranking in Table 2 were chosen many times as the most important or urgency project by respondents. From Table 2, it follows that the rankings of the importance and urgency are the same; $\mathrm{P}_{2}>\mathrm{P}_{1}>\mathrm{P}_{5}>\mathrm{P}_{6}>\mathrm{P}_{3}>\mathrm{P}_{4}$. Furthermore, it follows from Table 3 that projects $\mathrm{P}_{1}$ and $\mathrm{P}_{2}$ were chosen as the most important and urgent by members of the committee. This ranking was for the budget request for the next fiscal year.

By the way, there was a prior evaluation by only the administration. It had three types of evaluation, A, B, and C. The project with evaluation A is expected to apply for more budget than projects of $\mathrm{B}$ or $\mathrm{C}$. After all, what was asked us was to decide which projects are $\mathrm{A}, \mathrm{B}$, or $\mathrm{C}$, respectively. They decided that projects $\mathrm{P}_{2}$ and $\mathrm{P}_{5}$ were of $\mathrm{A}$ and the other projects of the basic strategy were of $\mathrm{B}$. As a result, these were almost the same as our evaluation mentioned above. On the other hand, the evaluation of $\mathrm{P}_{1}$ was different. According to Table 2, the importance of $\mathrm{P}_{1}$ is much more than that of $\mathrm{P}_{5}$, and the urgency of $\mathrm{P}_{1}$ is a little more than that of $\mathrm{P}_{5}$. From this, the evaluation of the importance of $\mathrm{P}_{1}$ was changed into $\mathrm{A}$ out of $\mathrm{B}$, though that of urgency remained $\mathrm{B}$. This result was a group decision by EBPM and democratic.

\section{Limitations}

The committee held the meeting eight times before doing a questionary survey. Through these meetings, we discussed these projects with administrative officers. So, we might have obtained almost the same result as the administrative officers. I need furthermore research to check that this method works well also without meetings, for example like a simple inhabitants' satisfaction investigation. However, regardless of a result, the significance that a citizen participated in an evaluation of projects for the request budget is big.

\section{Conclusions}

In this paper, I presented an example to show that the AHP is helpful and useful in the context of EBPM. Reconsidering the evaluation of those projects after one year was planned, but we could not do, because of COVID-19. However, we could notice the importance of a project of another strategy, which is the "Restructure of the commercerelated organization", and this evaluation was C at that time. We could fulfill accountability by a democratic evaluation of the importance and urgency of projects in Okaya city commerce activation plan despite this situation thanks to the AHP.

\section{Key References}

Ohashi, Hiroshi. (eds) (2020). Economic thinking for evidence-based policy making (in Japanese), University of Tokyo Press, Tokyo.

Osborne, David \& Gaebler, Ted. (1993). Reinventing government: How the entrepreneurial spirit is transforming the public sector. Plume, New York.

Saaty, T.L. (1994). Fundamentals of decision making and priority theory. Pittsburgh, PA: RWS Publications.

Stoker, Gerry \& Evans, Mark. (eds) (2016). Evidence-based policy making in the social sciences: Methods that matter. Bristol University Press, Policy Press. 